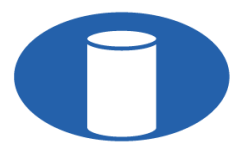

IBRACON

\title{
Effects of dowel bars misalignment in jointed plain concrete pavements - A numerical analysis considering thermal differentials and bonded slab-base interface
}

\author{
Efeitos do desalinhamento vertical e horizontal de barras de transferência de carga \\ em pavimentos de concreto simples - uma análise numérica considerando \\ diferenciais térmicos e aderência entre placa e base
}

Eric Ribeiro da Silva ${ }^{\text {a,b }}$ (D)

José Tadeu Balbo ${ }^{\text {a }}$ (i)

Andréia Posser Cargnin ${ }^{\mathrm{a}}$ (D)

${ }^{a}$ Universidade de São Paulo - USP, Departamento de Engenharia de Transportes, São Paulo, SP, Brasil

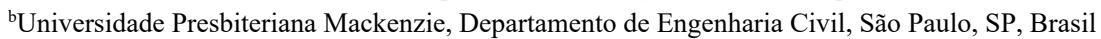

Received 17 May 2020

Accepted 16 November 2020

\begin{abstract}
Joints in concrete pavements are built to allow slab volumetric variations avoiding random cracks. Moreover, as they are discontinuities, the use of dowel bars prevents loss of load transfer across joints. During bars installation or even concrete casting, misalignments and misallocations of those devices may occur, affecting the concrete pavement structural performance. This study explores the effects of such nonconformities in the positioning of dowel bars through numerical modeling, using the $3 \mathrm{D}$ finite element program EverFE2.25. For, numerical simulations, bending stresses in concrete slabs of a typical bus corridor were ascertained, varying misalignments types and magnitudes (vertical tilt and horizontal skew), base type (cemented and asphalt), slab/base interface bond conditions and concrete thermal differential. Results disclosed the contribution of using bonded base in reducing stresses, even when the dowels were severely misaligned while slabs were subjected to high thermal differentials.
\end{abstract}

Keywords: plain concrete pavements, dowel bars misalignment, numerical analysis, structural evaluation.

Resumo: As juntas em pavimentos de concreto são construídas com o objetivo de permitir a expansão e contração do concreto quando de alterações nas condições climáticas, impedindo a ocorrência de fissuras de retração de secagem aleatórias. Contudo, como as juntas serradas causam descontinuidades nos pavimentos, gerando o formato típico das placas, as barras de transferência de carga são introduzidas para evitar que a capacidade de transferência de carga do pavimento de concreto seja reduzida. Quando do posicionamento dessas barras em pista e mesmo durante a concretagem do pavimento podem ocorrer desalinhamentos, que por sua vez podem afetar o desempenho estrutural e funcional do sistema mesmo de maneira precoce. Assim, a investigação dos efeitos de desconformidades no posicionamento dessas barras nas tensões de serviço em pavimentos de concreto simples, por meio de modelagem numérica, torna-se ponto de partida para a melhoria das especificações e restrições normativas sobre o assunto. Nesse estudo foram realizadas simulações numéricas por meio do Método dos Elementos Finitos, com o programa EverFE 2.25 (em 3D) de estrutura típica de pavimento de concreto simples em corredor de ônibus quando foram então avaliados os tipos e magnitudes de desalinhamentos (rotações verticais e horizontais), tipos de base (cimentada e asfáltica) de apoio das placas, condições de aderência entre placas e base, bem como ocorrência ou não de gradientes de temperatura entre topo e fundo da placa. Os resultados evidenciaram a significativa contribuição da aderência entre a placa de concreto e a base para a redução das tensões de tração na flexão no concreto, mesmo quando as barras se encontrassem severamente desalinhadas e as placas sujeitas a diferenciais térmicos elevados.

Palavras-chave: pavimentos de concreto simples, desalinhamento de barras de transferência de carga, análise numérica, avaliação estrutural.

Corresponding author: José Tadeu Balbo. E-mail: jotbalbo@usp.br

Financial support: CAPES - Foundation for the Coordination and Improvement of Higher Education Personal, Ministry of Education - by the Ph.D. scholarships provided to the first and third authors.

Conflict of interest: Nothing to declare. 
How to cite: E. R. Silva, J. T. Balbo, and A. P. Cargnin, "Effects of dowel bars misalignment in jointed plain concrete pavements - A numerical analysis considering thermal differentials and bonded slab-base interface," Rev. IBRACON Estrut. Mater., vol. 14, no. 4, e14414, 2021, https://doi.org/10.1590/S1983-41952021000400014

\section{INTRODUCTION}

One of the most specific characteristics in concrete pavements is the presence of contraction joints, normally built to enable the concrete expansion and contraction during its cure and under severe weather conditions, avoiding the occurrence of random shrinkage cracks [1], [2].

However, as joints create discontinuities in concrete pavements, their presence reduces the load transfer capacity, requiring, therefore, the introduction of a load transfer mechanism across these joints [3]. This is accomplished by using dowel bars, which enable partial transfer of stresses to the nearby slab, forcing successive slabs to work simultaneously in the joint limits (this effect is known as "load transfer") [4], [5]. Such bars have smooth surfaces and are greased prior to concrete pouring to allow the concrete slabs horizontal contraction and expansion movements since the they work detached from the dry concrete. The main mechanism of load transfer supplied at joints by dowel bars is shearing.

The load transfer mechanism between neighboring slabs decreases deflections and stresses at the slab's edges and corners, beyond helping to ensure a satisfactory pavement performance, preventing future distresses development such as corner breaks and pumping followed by faulting [6], [7].

Aiming to provide maximum load transfer capacity, the dowel bars are positioned parallel to the concrete slab bottom surface and pavement longitudinal axis, at the slab half-height [2], [4], [7]. Moreover they shall be longitudinally centered in the transverse joints and parallel to the direction of movement of the slabs in relation to joint; they may be also used at longitudinal joints in areas with random or non-directional traffic, as well as in diagonal directions load movements on concrete slabs [1]. Dowel bars are also greased to fully avoid adherence to concrete, allowing free horizontal movements.

The placement of such kind of load transfer mechanism in concrete pavements may be conducted in two different ways: using metal dowel baskets positioned and fixed on the pavement base before concrete casting; or using an automated mechanical dowel bar inserter attached to the concrete pavement machine, which places the dowel bars soon after concrete casting [4], [5], [7]. One should note that for both methods correct placement of the dowel bars is essential to guarantee good structural and functional pavement performance over its service life.

However, during the dowel bars placement, misalignment and misallocation may occur (Figure 1) due to lack of controlling their position and alignment, dowel baskets inappropriate stiffness, as well as failure when fixing the dowel baskets on the base, or even during the concrete casting. In the case of dowel bars inserter, concrete mixture design is considered the most critical factor influencing both dowel bars placement and its stability into the plastic concrete [8].

One of the main problems associated with the control of dowel bars alignment and positioning is the potential for locking the joint [9]. In the case of joints with dowel bars, alignment and positioning disagreements may affect the concrete slabs movements during its expansion and contraction (due to thermal and moisture changes) causing, consequently, the system malfunction, even leading to concrete transversal cracks parallel to the joints.

The locking of an isolated joint does not impair the pavement performance. Nevertheless, the risk of breaking the slab is increased when successive joints are locked due to joint restriction movements leading to spalling in the severe cases. Furthermore, the dowel bars vertical tilt should be limited in order to avoid shear cracks or spalling above or below the bars and a concrete minimum cover warranted to avoid the steel corrosion [7], [10].

For these reasons, dowel bars alignment and positioning have been of concern since the 1930s [10]. Most of the road agencies in developed countries with tradition on constructing concrete pavements set out tolerances for controlling dowel bars positioning and alignment during its placement.

Such limits are commonly expressed in terms of deviations at the dowel bar ends related to the designed position and its length (for instance, $6 \mathrm{~mm}$ for a dowel bar with length of $460 \mathrm{~mm}$ ) or in terms of percentage length. Some authors, nonetheless, present only rotating tolerances (horizontal skew and vertical tilt) in relation to the correct position through the dowel inclination (usually expressed in radians).

In Brazil, the misalignment tolerance for individual dowels related to its correct position accepted by road agencies [11], [12] corresponds to $\pm 1 \%$ of the bar length and at least two-thirds of the dowels in a single joint shall present a maximum deviation of $\pm 0,7 \%$. However, as shown in Table 1 , such tolerances do not match the typical standards applied in countries with a vast history on concrete pavement construction, like Germany and USA. 
MISALIGNMENT

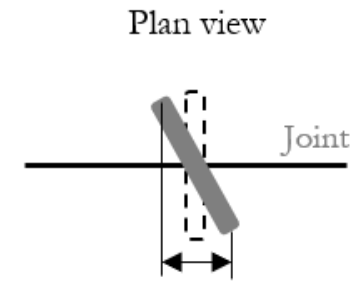

Horizontal skew
Section view

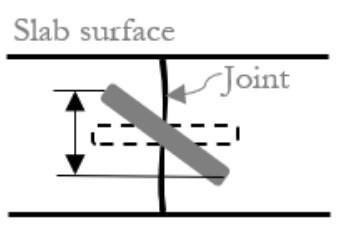

Slab bottom

Vertical tilt

MISLOCATION

Plan view

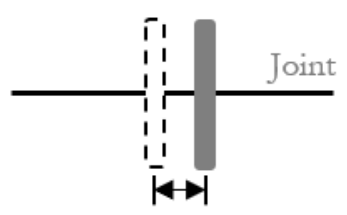

Horizontal translation
Plan view

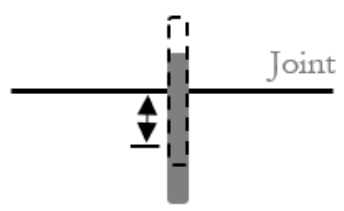

Longitudinal translation
Section view

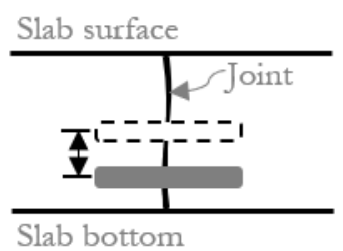

Vertical translation

Figure 1. Main misalignment and misallocation types in dowel bars (Source: Adapted from Tayabji [3]).

Table 1. Misalignment and misallocation tolerances.

\begin{tabular}{cccccc}
\hline Country & Vertical tilt & $\begin{array}{c}\text { Horizontal } \\
\text { skew }\end{array}$ & $\begin{array}{c}\text { Longitudinal } \\
\text { translation }\end{array}$ & $\begin{array}{c}\text { Vertical } \\
\text { translation }\end{array}$ & Source \\
\hline Brazil & $1.0 \%$ & $1.0 \%$ & $1.0 \%$ & $1.0 \%$ & DER-SP [11], DNIT [12] \\
\hline Germany & $4.2 \%$ & $4.2 \%$ & $11.1 \%$ & & Rao et al. [4] \\
\hline USA & $3.3 \%$ & $3.3 \%$ & $11.1 \%$ & $5.6 \%$ & FHWA [10], ACPA [9] \\
\hline
\end{tabular}

Over the last decades, investigations on concrete pavements mechanical behavior employing the finite element method (FEM) have increasingly spread. Most of these studies are concentrated on the load transfer efficiency analysis in concrete pavement joints with aligned dowel bars [13]. Only a limited number of investigations sought to understand the interaction mechanism between misaligned dowel bars and the concrete. Examples of such studies can be found elsewhere [13], [14], [15], [16].

However, these studies pursued to understand mainly the interaction mechanism between dowel bars and concrete slabs focused on the joint vicinity, investigating the stresses and the damage caused by the misalignment. Curling of slabs due to concrete curing and concrete top-bottom thermal differential, as well as the effects of bonding or not bonding the concrete to the underneath pavement stiff bases, are well understood as supporting factors to be taken into account on joint behavior analysis since they will interfere in the system response as a whole.

Thereby, the current study addresses the effects of dowel bars misalignment combined (horizontal skew and vertical tilt) with positive thermal gradient (mostly found in roads in tropical environments), comprising the bond effect given at the slab/base interface, on the structural response of a jointed-plain concrete pavement (JPCP), through numerical simulations using the FEM, accomplished by simulations applying EverFE 2.25 software [14].

\subsection{Justification}

Transversal joints are the most critical elements for plain concrete pavements performance. Depending on pavement bases capabilities to partially transfer loads from both sides of joints, flexural stresses on concrete slabs can increase when dowel bars are misplaced, and such alteration is not commonly considered in the structural design of concrete pavement structures by design guides. Furthermore, studying the dowel bars misallocations are of paramount 
importance for future standardization for building such structural devices in concrete pavements, either plain or reinforced ones.

\section{NUMERICAL MODEL DESCRIPTION}

The FEM software EverFE 2.25 was used in this study since it was developed specifically for JPCP analysis purposes, with an intuitive graphic interface (Figure 2), beyond it enables the parametric study of up to nine concrete slabs (in a $3 \times 3$ arrangement), settled on even three elastic layers and subgrade.

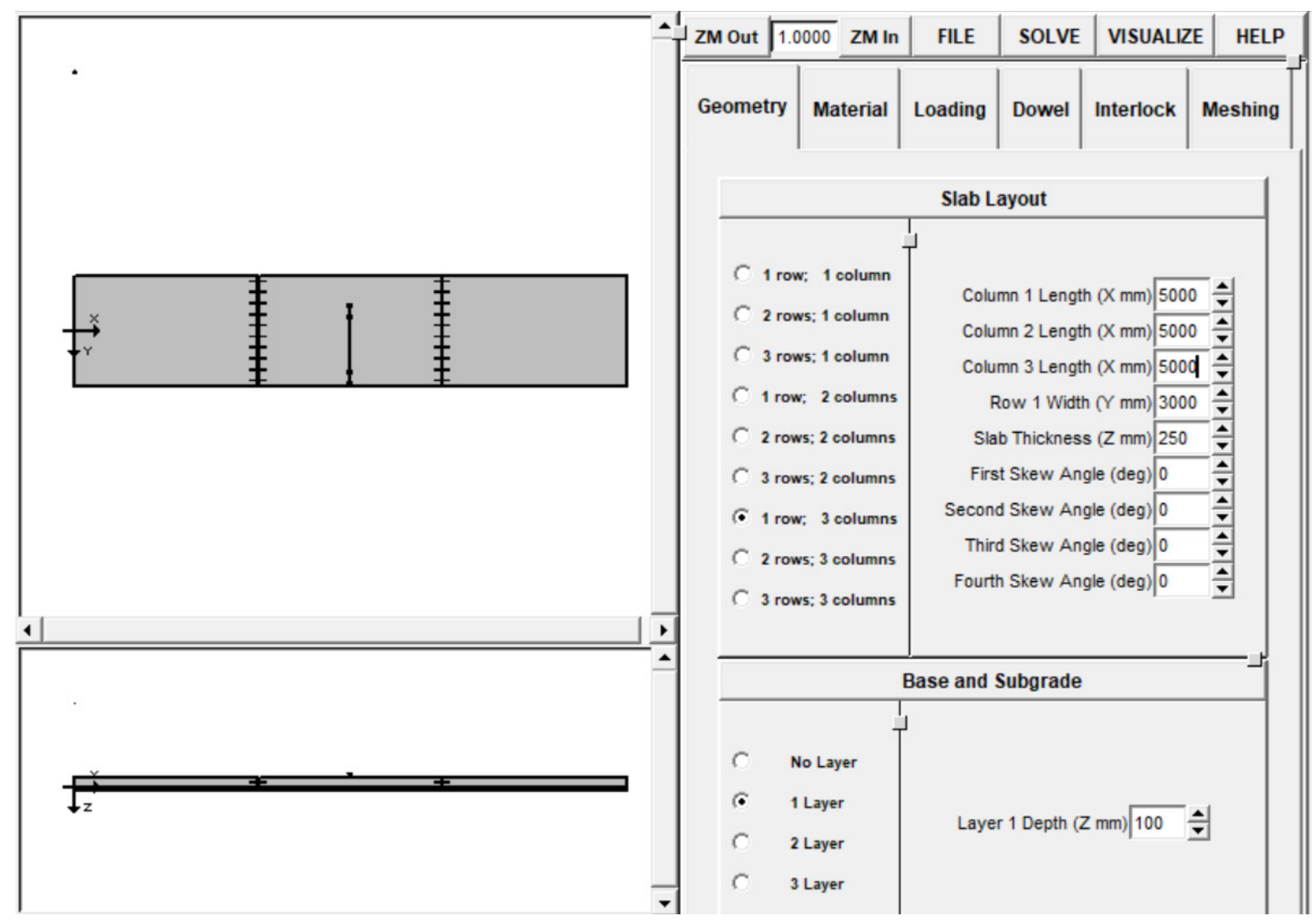

Figure 2. Example of the graphic interface in the software EverFE 2.25.

Additionally, EverFE 2.25 allows the analysis of linear and non-linear thermal gradient effects on concrete slabs, assessment of different concrete slab/base bond conditions, and the analysis of pavement structures with or without dowel bars in the transverse joints, as well as specification of dowel bars misalignments or misallocations. For models with lateral slabs, tie bars may be introduced in the longitudinal joints.

Concrete slabs and base layer are discretized by 20 -noded quadratic brick elements; the subgrade is discretized by 8-noded planar quadratic elements that incorporate the dense liquid foundation model and the load transfer by the aggregate interlocking at the joint; shear transfer at the slab/base interface is discretized by 16-noded quadratic interface elements [17], as illustrated in Figure 3.

Dowels and tie bars are molded by embedded flexural finite elements, which allow the precise location of dowels and tie bars, regardless the mesh lines, permitting relevant savings in the computing time, making easier the load transfer efficiency simulation without requiring a highly refined mesh at the joint limits [14]. 


\section{PLAN VIEW}

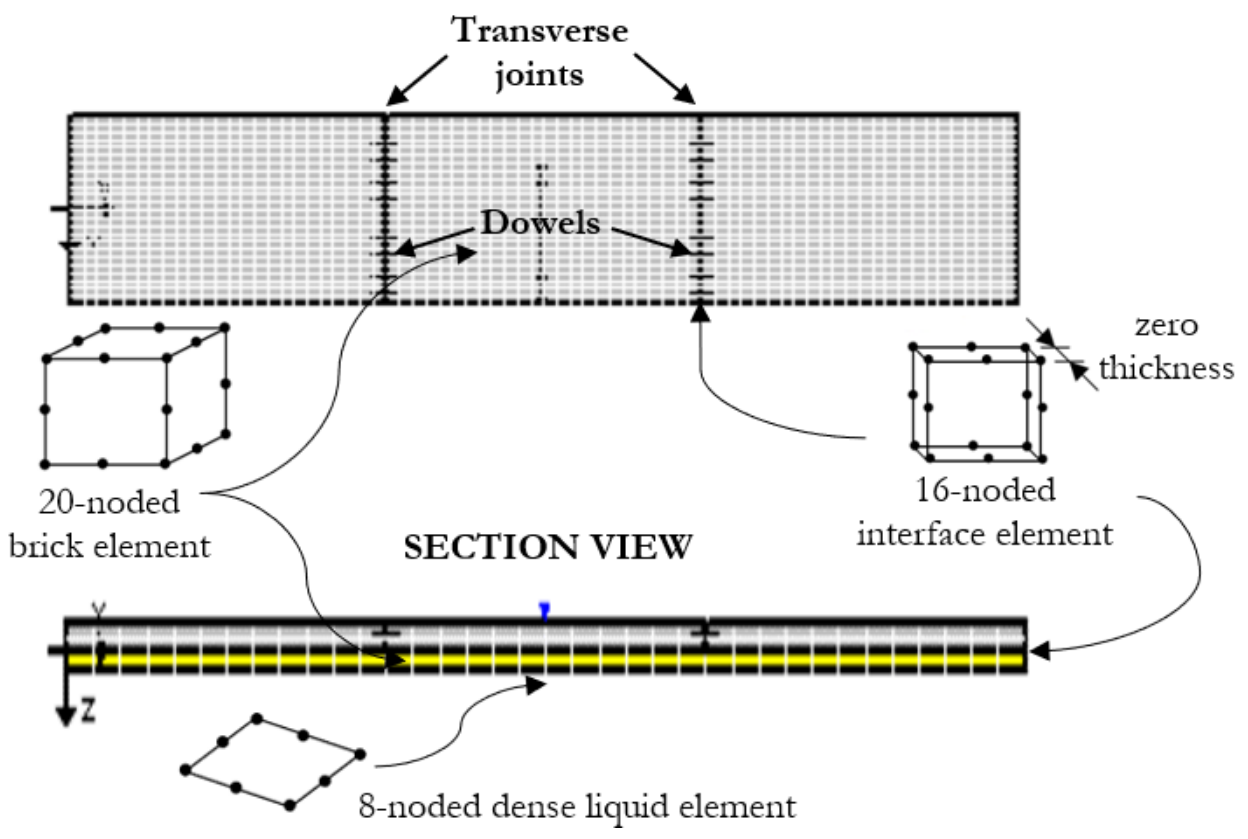

Figure 3. Finite elements used in the EverFE 2.25 discretization (Source: adapted from Davids et al. [14]).

The software algorithm pinpoints precisely the individual flexural elements inside the solid elements mesh, solving first the dowel bars intersection with the solid element faces and, afterwards, partitioning each dowel bar in at least 20 quadratic flexural elements individually incorporated [14].

EverFE 2.25 also allows to consider either the slab/base perfect bond or the full separation between them. In both cases, the concrete slab and base do not share nodes, and the nodal restraints are used to meet the contact conditions required [17]. The interaction degree at the concrete slab and base interface is defined through the shear stress $\left(\tau_{0}\right)$ and the relative slip $\left(\delta_{0}\right)$ ratio between the concrete slab and the base, characterized by an initial stiffness $k_{S B}(\mathrm{MPa} / \mathrm{mm})$, distributed in the horizontal direction [14], as depicted in Figure 4.

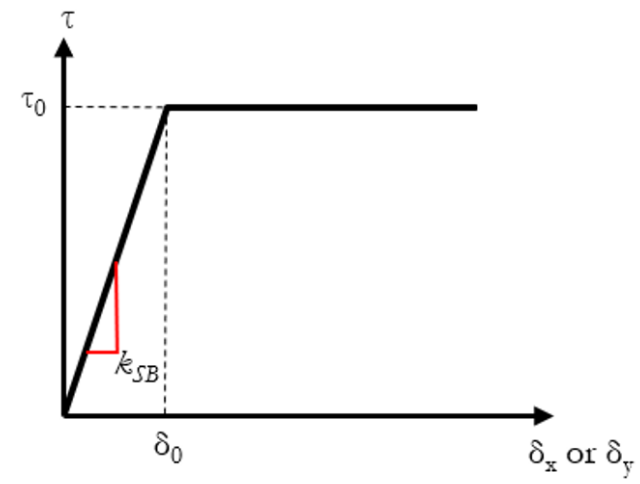

a) Interaction between the concrete slab and base layer

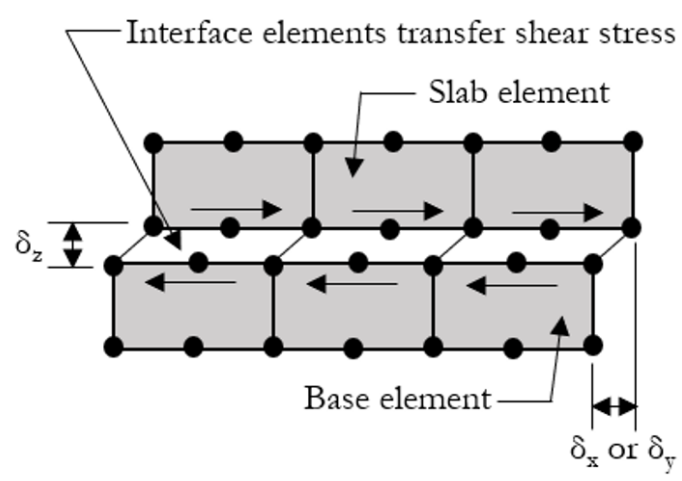

b) Shear transfer in the interface between the concrete slab and base layer

Figure 4. Shear transfer between the concrete slab and base layer modeling in the EverFE 2.25 (Source: adapted from Davids et al. [14]). 


\subsection{Concrete pavement structure modeling}

To simulate a typical bus corridor's structure, a system with three concrete slabs (in single lane) upon base layer and subgrade was employed. Concrete slabs simulated were $5.0 \mathrm{~m}$ long, $3.0 \mathrm{~m}$ wide and $250 \mathrm{~mm}$ thick.

The simulations were carried out in two steps. Firstly, concrete slabs over a $100 \mathrm{~mm}$ thick unbonded cement-treated base layer were simulated regarding the misalignment limits put in place by road authorities in order to verify how such limits affect the flexural stresses due to positive thermal differential. Joint openings of $0.5 \mathrm{~mm}$ and $1.25 \mathrm{~mm}$ were simulated as well to assess their impact on the stresses. It is worth to highlight that the joint opening is significantly limited in concrete slabs under tropical climate because the top-bottom average temperature in the coldest and hottest conditions are around 19.5 and $33^{\circ} \mathrm{C}$ [18], respectively, whereas the average temperature at the time of concrete set is around $27.5^{\circ} \mathrm{C}[19]$.

The second step comprised the simulations considering the dowel misalignments higher than the limits stablished by road authorities to check their impact on the concrete flexural stresses. Regarding the concrete pavement structures analyzed herein, simulations included bonded and unbonded cement-treated base as well as bonded and unbonded asphalt base; therefore, the pavement structures are three-layered systems comprising slab, base and subgrade.

For all the analyzed cases the modulus of subgrade reaction employed was $\mathrm{k}=30 \mathrm{MPa} / \mathrm{m}$ for a fair elastic soil. Table 2 summarizes the parameters adopted in the 752 cases analyzed in the numerical simulations.

Table 2. Parameters and values adopted for numerical simulations.

\begin{tabular}{|c|c|c|}
\hline Parameter & Unit & Value adopted \\
\hline Concrete slab thickness & $\mathrm{mm}$ & 250 \\
\hline Cement treated base thickness & $\mathrm{mm}$ & 100 \\
\hline Asphalt base thickness & $\mathrm{mm}$ & 60 \\
\hline Modulus of elasticity (concrete) & $\mathrm{MPa}$ & 30,000 \\
\hline Modulus of elasticity (cement-treated base) & $\mathrm{MPa}$ & 11,000 \\
\hline Modulus of elasticity (asphalt base) & $\mathrm{MPa}$ & 7,000 \\
\hline Poisson ratio (concrete) & - & 0.15 \\
\hline Poisson ratio (cement-treated material) & - & 0.20 \\
\hline Poisson ratio (asphalt mix) & - & 0.30 \\
\hline Modulus of subgrade reaction & $\mathrm{MPa} / \mathrm{m}$ & 30 \\
\hline Concrete slabs length & $\mathrm{mm}$ & 5,000 \\
\hline Concrete slabs width & $\mathrm{mm}$ & 3,000 \\
\hline Thermal differential & ${ }^{\circ} \mathrm{C}$ & $0 ; 5 ; 10 ; 15$ and 20 \\
\hline Single Axle Load & $\mathrm{kN}$ & 80 \\
\hline Dowel bars length & $\mathrm{mm}$ & 460 \\
\hline Dowel bars diameter & $\mathrm{mm}$ & 32 \\
\hline Distance between dowel bars & $\mathrm{mm}$ & 300 \\
\hline Dowel bars' modulus of elasticity & $\mathrm{MPa}$ & 210,000 \\
\hline Dowel bars' Poisson ratio & & 0.3 \\
\hline
\end{tabular}

The non-adherence condition between the concrete slab and the cement-treated base was defined in the EverFE 2.25 assuming a low interaction degree in the slab/base interface through the shear stress and relative slip ratio between the concrete slab and the base layer. So, it was admitted an initial shear stiffness distributed along the horizontal direction $\mathrm{kSB}=0,0001 \mathrm{MPa} / \mathrm{mm}$ (expected value when a polyethylene plastic canvas is used on the base before concrete casting to avoid the adhesion between the concrete slab and base) [14]. 
Loading was simulated considering the effect of an $80 \mathrm{kN}$ single dual wheel axle, positioned on the central slab longitudinal edge, with one of the wheels very close to the slab edge, and centered on the middle. Moreover, linear positive thermal differential between the slab top and bottom ranging from $0^{\circ} \mathrm{C}$ to $20^{\circ} \mathrm{C}$ were simulated.

Each transverse joint has 10 dowel bars with $32 \mathrm{~mm}$ of diameter and length of $460 \mathrm{~mm}$, positioned each $300 \mathrm{~mm}$ along the joint. It was also assumed the dowel bars were not bonded to the concrete and there was no looseness between them and the surrounding concrete.

For all the analyzed cases the finite elements mesh was identical for both directions $\mathrm{x}$ and $\mathrm{y}$, employing 24 elements in the plane and element along the slab cross-section.

\subsection{Dowel bars positioning at transverse joints}

In order to investigate the effects of dowel bars misalignment on JPCP maximum flexural stresses, the following conditions were simulated:

- Dowel bars properly positioned (aligned).

- Uniform horizontal skew (UHS) with all dowel bars presenting the same rotation in the plane (x,y).

- Non-uniform horizontal skew (NUHS) with all dowel bars presenting the same rotation in the plane (x,y), alternating the rotation direction (clockwise and anticlockwise) of successive bars.

- Uniform vertical tilt (UVT) with all dowel bars presenting the same rotation in the plane (x,z).

- Non-uniform vertical tilt (NUVT) with all dowel bars presenting the same rotation in the plane (x,z), alternating the direction rotation (clockwise and anticlockwise) of successive bars.

The amplitude of the dowel bars misalignments assumed in the second step of the numerical simulations are described in Table 3, wherein the misalignment corresponding values in rad, degrees, and percentages are presented.

Table 3. Amplitude of the dowel bars misalignment considered for simulations.

\begin{tabular}{ccc}
\hline & Misalignment amplitude & $\%$ \\
\hline rad & degrees & 0 \\
\hline 0 & 0 & 2.78 \\
\hline $1 / 36$ & 1.59 & 5.56 \\
\hline $1 / 18$ & 3.18 & 8.33 \\
\hline $1 / 12$ & 4.77 & 11.11 \\
\hline $1 / 9$ & 6.37 & 16.67 \\
\hline $1 / 6$ & 9.55 & 25.00 \\
\hline $1 / 3$ & 14.32 & 33.33 \\
\hline
\end{tabular}

Dowel bars definitions in the EverFE 2.25 software are implemented in the "Dowel" flap (Figure 5); clicking on any one dowel bar opens a window (Figure 6) which allows the user to define the translations in the directions $\mathrm{x}$ and $\mathrm{z}$, as well as the rotations in the plane (x,y) attributing values to "alpha" angle and in the plane $(\mathrm{y}, \mathrm{z})$ giving values to "beta" angle, both in degrees. This parametrization may be performed individually, or the same configuration can be applied for all dowel bars in a certain transverse joint (in case of uniform misalignments). 


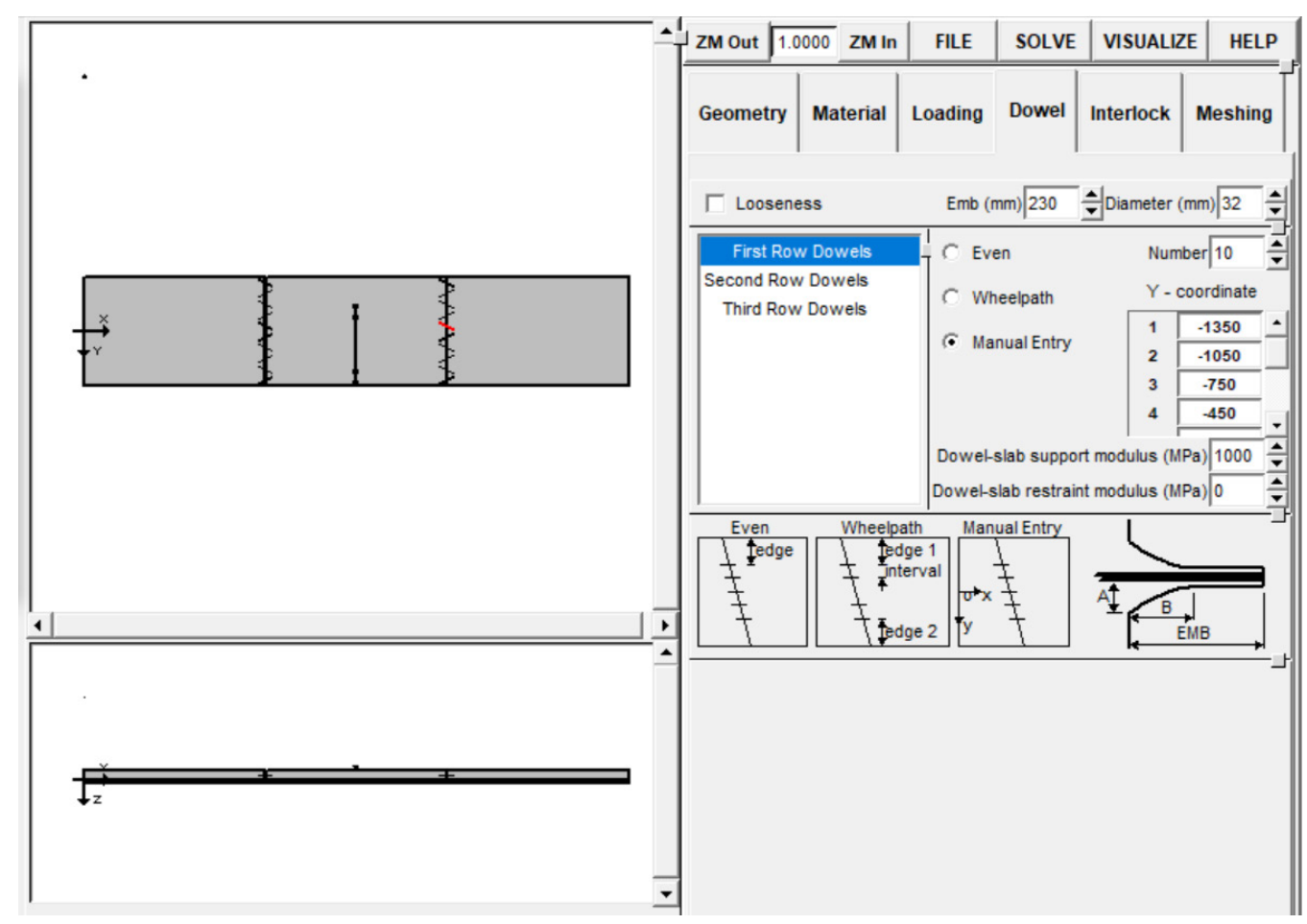

Figure 5. EverFE 2.25 flap for parametrizing dowel bars characteristics in transverse joints.

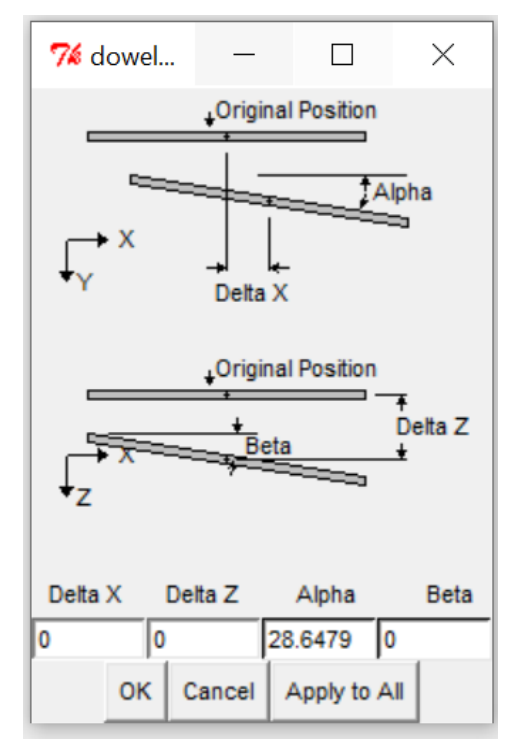

Figure 6. EverFE 2.25 window for determining dowel bars positions in the transverse joints.

\section{RESULTS AND DISCUSSIONS}

\subsection{Analysis of dowel bars properly positioned}

Firstly, it was assessed the thermal gradient effects on the maximum flexural stresses, i.e., when the simulations involved the dowel bars positioning compliance along the transverse joints (Figure 7). One should note that the slab/base adherence causes an expressive reduction on the maximum stresses for high thermal differential because of the neutral axis displacement towards the slab bottom [1]. 


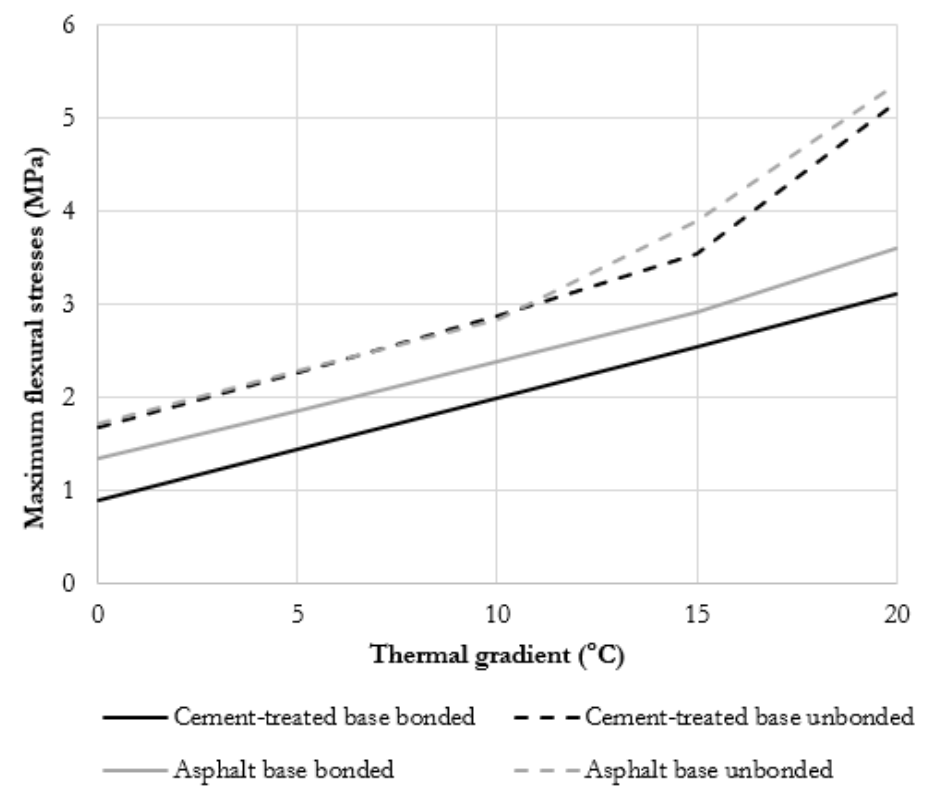

Figure 7. Thermal gradient effect on the maximum flexural stresses when dowel bars are properly positioned.

In addition, when the concrete slab and base were bonded, the maximum flexural stresses were always recorded at the bottom of the concrete slab. However, when the concrete slab was unbounded to cement-treated base, for a thermal gradient of $20^{\circ} \mathrm{C}$, the maximum stress was recorded at the top of the concrete slab; otherwise, for asphalt base unbounded to the concrete slab and thermal differential of $15^{\circ} \mathrm{C}$ and $20^{\circ} \mathrm{C}$, the maximum flexural stresses were recorded at the middle of the concrete slab.

Comparing the thermal gradient effects considering bond between slab and base, it was observed that maximum flexural stresses were about $14 \%$ to $50 \%$ higher when the asphalt base was considered rather than the cement-treated base.

On the other hand, considering slab unbounded to base it was observed that, for thermal gradient up to $10^{\circ} \mathrm{C}$, the maximum flexural stresses were almost the same. Only for cases with thermal differential of $15^{\circ} \mathrm{C}$ and $20^{\circ} \mathrm{C}$ the maximum flexural stresses recorded in asphalt base were $10 \%$ and $4 \%$ higher, respectively, than values got for cement-treated base.

\subsection{Analysis of the joint opening and thermal differentials on the dowel bars misalignments limits admitted by road authorities}

Results obtained from simulations combining the joint opening and dowel bars misalignment limits put in place by road authorities in Brazil, the United Stated and Germany are presented in Table 4.

Table 4. Maximum principal stresses caused by joint opening.

\begin{tabular}{|c|c|c|c|c|c|c|}
\hline \multicolumn{2}{|c|}{ Misalignment amplitude } & \multirow{2}{*}{ Joint opening } & \multicolumn{4}{|c|}{ Maximum principal stresses (MPa) } \\
\hline degrees & $\%$ & & UVT & UHS & NUVT & NUHS \\
\hline 0.00 & 0.0 & 0.50 & 1.686 & 1.686 & 1.686 & 1.686 \\
\hline 0.57 & 1.0 & 0.50 & 1.686 & 1.686 & 1.686 & 1.686 \\
\hline 1.89 & 3.3 & 0.50 & 1.687 & 1.686 & 1.686 & 1.686 \\
\hline 2.41 & 4.2 & 0.50 & 1.687 & 1.686 & 1.686 & 1.686 \\
\hline 0.00 & 0.0 & 1.25 & 1.686 & 1.686 & 1.686 & 1.686 \\
\hline 0.57 & 1.0 & 1.25 & 1.686 & 1.686 & 1.686 & 1.686 \\
\hline 1.89 & 3.3 & 1.25 & 1.687 & 1.686 & 1.686 & 1.686 \\
\hline 2.41 & 4.2 & 1.25 & 1.687 & 1.686 & 1.686 & 1.686 \\
\hline
\end{tabular}


The joint opening was simulated taking into account that, in tropical climate, the fluctuation in the concrete slab average temperature between the coldest and hottest condition is around $13.5^{\circ} \mathrm{C}$, so that the joint width due to the slab contraction is significantly limited, roughly $0.75 \mathrm{~mm}$.

The results for the different misalignment types (UHS, NUHS, UVT and NUVT) in Table 4 show the stress variation due to joint opening is markedly low, limited to $0.06 \%$ regarding the tropical climate characteristics.

The stress results combining the dowel bars misalignment and the concrete slab thermal differential are presented in Table 5. It is noted the increase in the flexural stresses due to dowels misalignment is too low when the tolerances fixed by the road authorities are considered.

Table 5. Maximum principal stresses caused by misalignment and thermal differential.

\begin{tabular}{|c|c|c|c|c|c|c|}
\hline \multicolumn{2}{|c|}{ Misalignment amplitude } & \multirow{2}{*}{$\Delta \mathrm{T}\left({ }^{\circ} \mathrm{C}\right)$} & \multicolumn{4}{|c|}{ Maximum principal stresses (MPa) } \\
\hline degrees & $\%$ & & UVT & UHS & NUVT & NUHS \\
\hline 0.00 & 0.0 & 0 & 1.686 & 1.686 & 1.686 & 1.686 \\
\hline 0.57 & 1.0 & 0 & 1.686 & 1.686 & 1.686 & 1.686 \\
\hline 1.89 & 3.3 & 0 & 1.687 & 1.686 & 1.686 & 1.686 \\
\hline 2.41 & 4.2 & 0 & 1.687 & 1.686 & 1.686 & 1.686 \\
\hline 0.00 & 0.0 & 5 & 2.271 & 2.271 & 2.271 & 2.271 \\
\hline 0.57 & 1.0 & 5 & 2.271 & 2.271 & 2.271 & 2.271 \\
\hline 1.89 & 3.3 & 5 & 2.271 & 2.271 & 2.271 & 2.271 \\
\hline 2.41 & 4.2 & 5 & 2.271 & 2.271 & 2.271 & 2.271 \\
\hline 0.00 & 0.0 & 10 & 2.873 & 2.873 & 2.873 & 2.873 \\
\hline 0.57 & 1.0 & 10 & 2.873 & 2.873 & 2.873 & 2.873 \\
\hline 1.89 & 3.3 & 10 & 2.873 & 2.873 & 2.873 & 2.873 \\
\hline 2.41 & 4.2 & 10 & 2.873 & 2.873 & 2.873 & 2.873 \\
\hline 0.00 & 0.0 & 15 & 3.530 & 3.530 & 3.530 & 3.530 \\
\hline 0.57 & 1.0 & 15 & 3.532 & 2.873 & 3.756 & 3.530 \\
\hline 1.89 & 3.3 & 15 & 3.532 & 3.531 & 3.532 & 3.532 \\
\hline 2.41 & 4.2 & 15 & 3.532 & 3.531 & 3.532 & 3.532 \\
\hline 0.00 & 0.0 & 20 & 5.169 & 5.169 & 5.169 & 5.169 \\
\hline 0.57 & 1.0 & 20 & 5.172 & 5.170 & 5.171 & 5.170 \\
\hline 1.89 & 3.3 & 20 & 5.178 & 5.171 & 5.174 & 5.171 \\
\hline 2.41 & 4.2 & 20 & 5.181 & 5.170 & 5.177 & 5.171 \\
\hline
\end{tabular}

One should note the result from simulation comprising the non-uniform vertical tilt (NUVT) of $1 \%$ and thermal differential of $15^{\circ} \mathrm{C}$; it is observed the maximum stress obtained in this specific combination is higher than maximum stress obtained for NUVT values of $3.3 \%$ and $4.2 \%$ considering the same thermal differential. This is a counterintuitive result which might be related to limitations in the numerical model employed.

\subsection{Combined effect analysis of thermal gradients and dowel bars placement non-conformities}

Analyzing the combined effects of thermal differential and dowel bars placement non-conformities on the flexural stresses, it was noted that, in general, the flexural stress rise was lower than $0.5 \%$ in cases with thermal differential beneath $10^{\circ} \mathrm{C}$. 
In cases with concrete slab bonded to the base layer, dowel bars placement disagreements lead to small growth in the flexural stresses with maximum values around $0.3 \%$ higher than maximum stresses obtained when dowel bars were properly placed.

On the other hand, for the slab to base unbounded condition the flexural stresses with dowel bars misaligned were $6.4 \%$ and $13.2 \%$ higher for asphalt and cement-treated base, respectively, compared to structures exposed to the same thermal differential, but without dowel bars misalignments.

Thereby, the obtained results spotlight the positive effect of bonding concrete slab and base layer on reducing concrete slab flexural stresses even when the dowel bars sharply misaligned and the slabs are submitted to high thermal differential.

The maximum flexural stresses obtained for the bonded condition under thermal differential of $20^{\circ} \mathrm{C}$ and different misalignments are depicted in Figure 8, whereas the maximum flexural stresses obtained for asphalt base layer situation and similar conditions are illustrated in Figure 9.

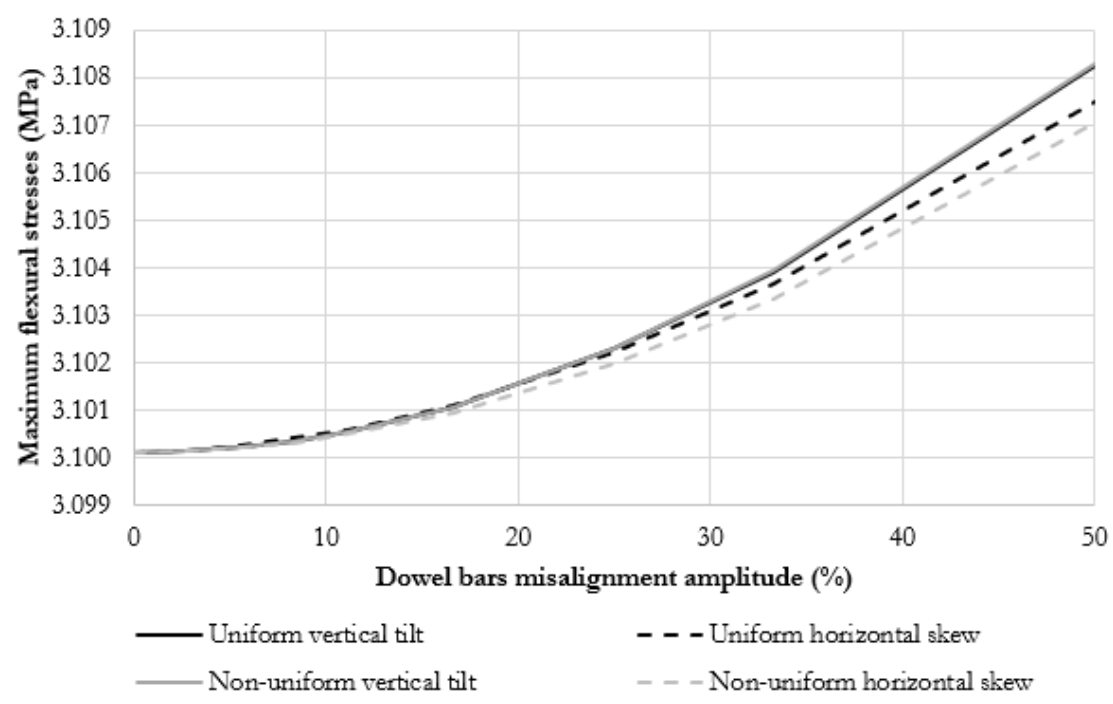

Figure 8. Flexural stresses in concrete slab bonded to cement-treated base for top-bottom thermal differential of $20^{\circ} \mathrm{C}$.

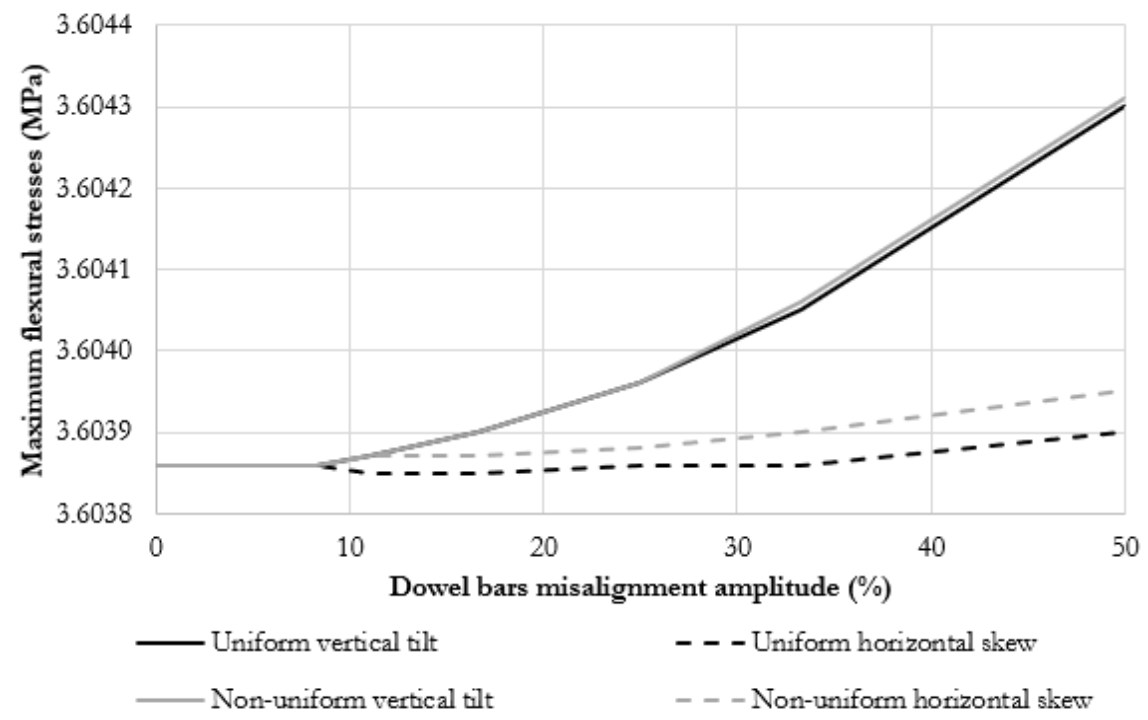

Figure 9. Flexural stresses in concrete slab bonded to asphalt base for top-bottom thermal differential of $20^{\circ} \mathrm{C}$. 
These results show that even in extreme misalignment conditions, combined with high thermal differential, the flexural stresses growth has a small extent when the concrete slab and base are fully bonded.

Figures 10 and 11 show the results obtained considering the same type of misalignment. In Figure 10 are presented the structural response curves regarding the magnitude of the dowel bars uniform horizontal skew expressed in terms of percentage (horizontal axle) on the maximum flexural stresses for the several cases investigated using cement-treated base, whereas in Figure 11 are presented the respective results considering the asphalt base option.

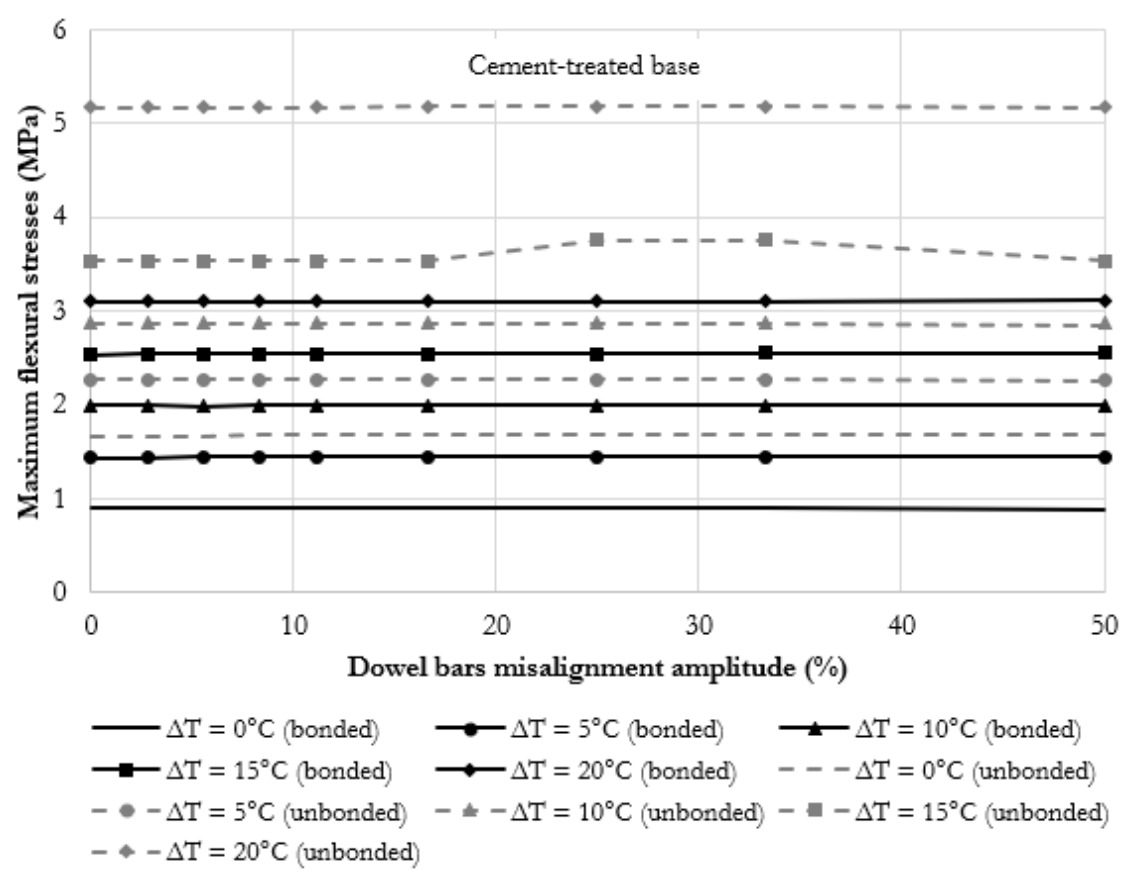

Figure 10. Flexural stresses in concrete slabs placed over cement-treated base according to dowel bars uniform horizontal skew and thermal differential.

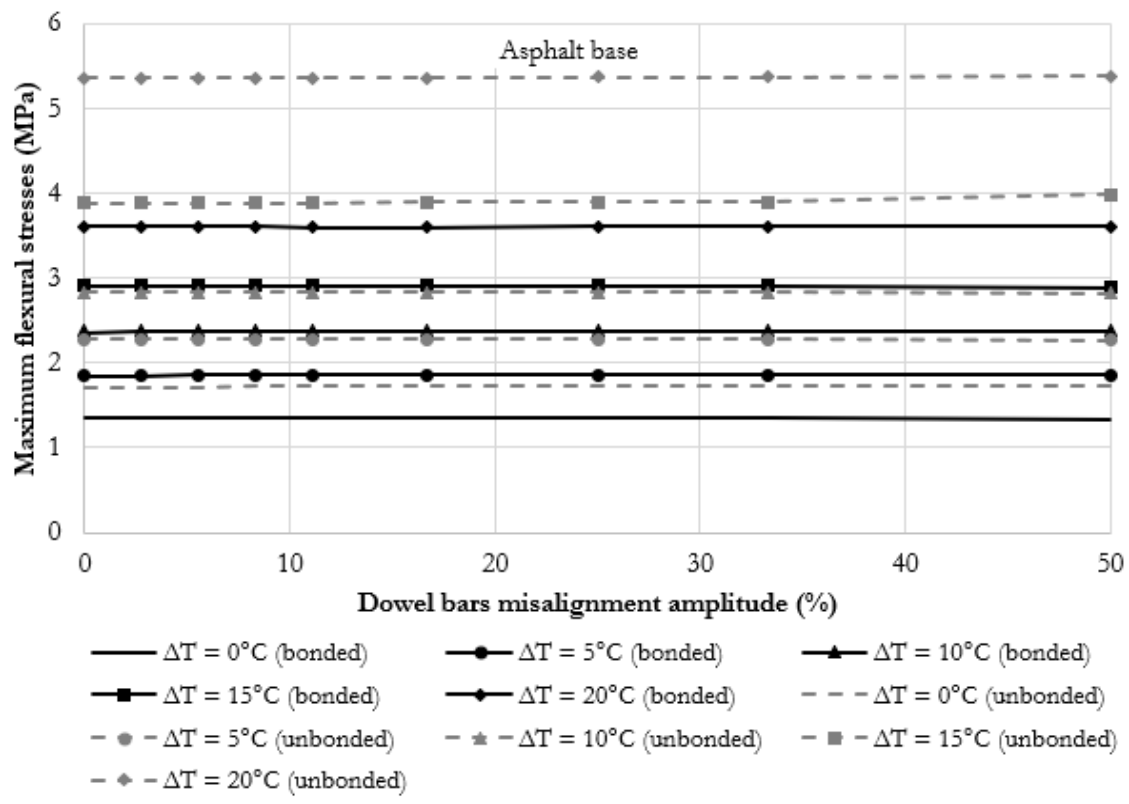

Figure 11. Flexural stresses in concrete slabs placed over asphalt base according to dowel bars uniform horizontal skew and thermal differential. 
In Figure 12 are depicted a colormap with the principal stresses in the concrete slabs and their deformed shape regarding unbonded cement-treated base, uniform horizontal skew of $16.67 \%$ and thermal differential of $20^{\circ} \mathrm{C}$.

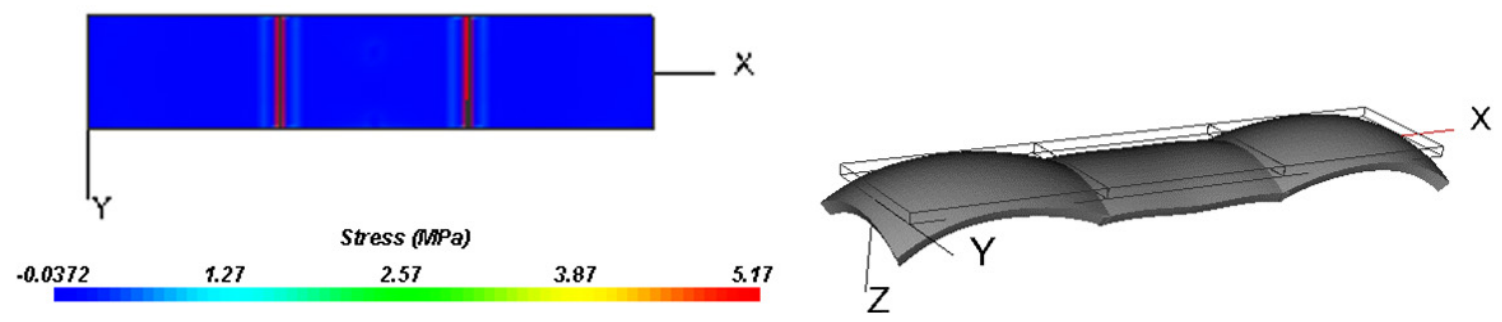

Figure 12. Example of the principal stresses colormap and the deformed shape of the system.

\section{CONCLUSIONS}

This study sought to investigate the effects of dowel bars misalignments on the maximum flexural stresses for a JPCP through numerical modeling using the FEM software EverFE 2.25. So, it was simulated a typical bus corridor's structure with bars submitted to different misalignment magnitudes and types combined with positive thermal differential. The joint opening effect on the stresses due to dowel bars misalignment regarding the limits put in place by the road authorities for structures under tropical climate characteristics was analyzed as well. Additionally, the investigations included the effect of base type (cement-treated and asphalt mixture) as well as the bonding conditions between concrete slab and base. The result analyses allow summarizing the main findings as follows:

- When the dowel bars are properly positioned and the concrete slab is unbounded to base, with thermal differential up to $10^{\circ} \mathrm{C}$, it was observed the maximum flexural stresses were roughly the same. Only for thermal differential of $15^{\circ} \mathrm{C}$ and $20^{\circ} \mathrm{C}$, the maximum flexural stresses were higher for asphalt mix base than cement-treated base, considering they unbounded beneath the concrete slab.

- As the difference between the concrete slab average temperature for the coldest and the hottest condition in rather unexpressive in tropical climate, the stress increments du to joint opening obtained from numerical simulations were minor and can be spared.

- For thermal differential lower than $10^{\circ} \mathrm{C}$, even regarding dowel bars sharply misaligned, the increase in the maximum flexural stress was very small and they may be spared.

- Dowel bars misalignments did not induce significant increase in flexural stresses during simulations, considering the concrete slab bonded to the base layer.

- Dowel bars misalignments caused relevant increases on the flexural stresses of $6.4 \%$ and $13.2 \%$, respectively, for asphalt mix and cement-treated base unbounded to the upper slab, compared to structures under the same conditions but with dowel bars positioned properly.

Thereby, slab/base bonding contributes expressively to reduce slab flexural stresses, even when the dowel bars are sharply misaligned, and the concrete slab is submitted to high thermal differential. Such a contribution affects positively the pavement durability in front of damages caused by the concrete fatigue process. Further research on this field will permit to issue consistent standard for of dowel bars installation, uses and toleration of its misalignment, pursuing for the best pavement performance.

In view of actual under certification of manpower for concrete pavement construction in developing countries where such a pavement choice is not a tradition, what brings worst scenarios about dowel bars installation control, as well as the bond effect between slabs and bases beneficial for reducing environmental loads effects, the main conclusion of the current study is to promote the best efficient construction method even under labor inability: to specify construction procedures to fully grease the dowel bars and simultaneously to bind the fresh concrete to the bases; such directive shall improve the concrete pavement transversal joints performance as a whole. This decision must be accomplished in the design phases and not left for site construction period possible considerations.

At last, to ensure full bond condition at the interface slab/asphalt mix it is required the use of a special binder coat over the asphalt base surface prior to concrete laying, what is well accomplished through the use of epoxy primers; however, costs shall be a concern before specifying such binders due to large surface areas to be treated in pavement construction. 


\section{ACKNOWLEDGEMENTS}

The authors are grateful to CAPES - Foundation for the Coordination and Improvement of Higher Education Personal Ministry of Education - by the Ph.D. scholarships provided to the first and third authors.

\section{REFERENCES}

[1] J. T. Balbo, Pavimentos de Concreto, São Paulo: Editora Signer, 2009.

[2] K. Hoegh and L. Khazanovich, "Laboratory investigation of misaligned dowel behavior," J. Test. Eval., vol. 38, no. 1, pp. 127-135, 2010.

[3] S. D. Tayabji, "Dowel placement tolerances for concrete pavements," Transp. Res. Rec., vol. 1, pp. 47-54, 1986.

[4] S. Rao et al., "Evaluation of dowel constructability in Portland cement concrete pavements," Transp. Res. Rec., no. 2098, pp. 86-93, 2009. http://dx.doi.org/10.3141/2098-09.

[5] T. Sturges, A. Frankhouser, and A. R. Abbas, "Evaluation of dowel bar alignment from a two-step dowel bar insert," Int. J. Pavement Eng., vol. 15, no. 5, pp. 438-448, 2014. http://dx.doi.org/10.1080/10298436.2013.815354.

[6] American Concrete Pavement Association, Design and Construction of Joints for Concrete Streets, Skokie: Concrete Information, 1992.

[7] Federal Highway Administration, Concrete Pavement Joints (Technical Advisory, T 5040.30). Washington: Federal Highway Administration, 2019.

[8] American Concrete Pavement Association, Evaluating and Optimizing Dowel Bar Alignment (Concrete Pavement Research and Technology (Special Report). Skokie, Illinois: ACPA, 2006.

[9] American Concrete Pavement Association, Dowel Bar Alignment and Location for Placement by Mechanical Dowel Bar Insertion. Guide Specification. Skokie, Illinois: ACPA, 2013.

[10] Federal Highway Administration, Best Practices for Dowel Placement Tolerances. Tech Brief-Concrete Pavement Technology Program, HIF-07-021, 2007.

[11] Departamento de Estradas de Rodagem do Estado de São Paulo, Pavimento de Concreto de Cimento Portland sobre Plataforma de Terraplenagem - Manual. DER-SP ET-DE-P00/039, 2007.

[12] Departamento Nacional de Infraestrutura de Transportes, Pavimento Rígido - Execução de Pavimento Rígido com Equipamento de Fôrmas Deslizantes - Especificação de Serviço, DNIT 049/2013-ES, 2013.

[13] M. Prabhu, A. H. Varma, and N. Buch, "Experimental and analytical investigation of mechanistic effects of dowel misalignment in jointed concrete pavements," Transp. Res. Rec., no. 2037, pp. 12-29, 2007. http://dx.doi.org/10.3141/2037-02.

[14] W. Davids et al., "Three-dimensional finite element analysis of jointed plain concrete pavement with EverFE2.2," Transp. Res. Rec., no. 1853, pp. 92-99, 2003. http://dx.doi.org/10.3141/1853-11.

[15] P. Leong et al., "Finite difference modeling of misaligned dowel bars and their effects on joint performance," Transp. Res. Rec., no. 1946, pp. 101-110, 2006. http://dx.doi.org/10.1177/0361198106194600112.

[16] P. Saxena et al., "Laboratory and analytical modelling of dowel," Int. J. Pavement Eng., vol. 13, no. 3, pp. 209-215, 2012. http://dx.doi.org/10.1080/10298436.2011.596936.

[17] W. Davids, EverFE Theory Manual. Orono: Department of Civil and Environmental Engineering, University of Maine, 2003.

[18] J. T. Balbo, and A. A. Severi, "Thermal gradients in concrete pavements in tropical environment: Experimental appraisal," Transp. Res. Rec., vol. 1809, no. 1, pp. 12-22, 2002. http://dx.doi.org/10.3141/1809-02.

[19] A. P. Cargnin, and J. T. Balbo, "Field calibration of shrinkage crack width model for CRCP in tropical climate," J. Transp. Eng. Part B Pavements, vol. 146, no. 3, 2020. http://dx.doi.org/10.1061/JPEODX.0000209.

Author contributions: ERS: data curation, formal analysis, methodology, writing, conceptualization; JTB: methodology, writing, funding acquisition, supervision, revision and APC: writing, translation, revision.

Editors: Osvaldo Manzoni, Guilherme Aris Parsekian. 